\title{
Assessment of the Larvicidal Efficacy of the Hexane-Leaf-Extracts of Selected Tropical Plant Species
}

\author{
Bawo D. D. $\mathbf{S}^{1}$, Ayodele A. Oyedeji ${ }^{1}$, Patrick B. Solomon ${ }^{1}$, Frankland O. Briyai ${ }^{1}$, Jasper F. \\ N Abowei ${ }^{1}$ \\ ${ }^{1}$ Department of Biological Sciences, Niger Delta University, Wilberforce Island, Nigeria \\ ayodele.oyedeji@yahoo.com
}

\begin{abstract}
The proliferation of mosquito vector in tropical countries has increased the prevalence of malaria with high morbidity and mortality burden. This research is concerned with the biolarvicidal efficacies of Cassia alata, Microdesmis puberula, and Spilanthes filicaulis extracted with hexane solvent, and screened against mosquito larva. Results on the negative control had no mortality on the larvae compared to the positive control, which had total mortality $(p<0.05)$. The C. alata plant extracts was the most active with LC50 value of 25.26 ppm, followed by; M. puberula (32.83 ppm), and S. filicaulis (36.46 ppm). Based on the outcome of the larvicidal bioassay, Hexane-leaf-extracts of all plants can be recommended for the formulation of biolarvicide due to their efficacies.
\end{abstract}

Keywords: Mosquito; Malaria; Biolarvcide; Methanolic-extract

\section{Introduction}

Malaria diseases are a major problem ravaging the tropical county. Statistically, malaria was reported to affect over 3.5 billion persons annually (Ohimain et al., 2014). It was also reported in literature that there are over 100 countries, with about 700 million incidence of malaria, especially tropical Region (Okumu et al., 2007). Malaria disease has been reported in the many developing countries in especially in Africa.

There are diverse species of mosquitoes that exist in nature, but around 30 - 40 species were reported to be carriers of the plasmodium parasite (Ghosh et al., 2007). In Africa, the most endemic transmitter of malaria is the female species of Anopheles gambiae and An. Arabiensis (Okumu, et al., 2007; Angaye, et al., 2014a; 2014b; Hamza et al., 2014; Owoeye et al., 2016).

According to Angaye (2015), the therapeutic efficacy of plant is not farfetched because plant produce elaborate metabolites as their genetic makeup, defence mechanisms and otherwise. As reported by Devappa, et al., (2010), tannins produced by some plants have ability to retard the palatability, nutrient absorption and growth rate of predators. These metabolites found in plant, these includes about 10,000 and 25,000 alkaloids and terpenes respectively (Cheeke, 1998).

There are several compounding factors responsible for plant efficacies as antioxidant; this include age of the plant, location, season and even ability of the plant to withstand harsh environment (Devappa et al., 2010; Angaye, 2015), or even the part of the plant (root, stem, fruits, leaves, and seeds) and/or applied solvent used for the bioassay (Angaye, 2015). Therefore, this investigation on the larvicidal efficacies of the hexane extracts of $C$. alata, $M$. puberula, and S. filicaulis.

\section{Material and Method}

\subsection{Collection and Preparation of Plant Samples}

The fresh leaves of $C$. alata, M. puberula and S. filicaulis were collected from vegetation around Wilberforce Island in Southern Ijaw Local Government Area of Bayelsa State, Nigeria. The plants were identified, washed and shade-dried for 7 days. The shade-dried plants were 
placed in oven at $50^{\circ} \mathrm{C}$ for 30 minutes (Angaye et al., 2017a; Angaye et al., 2017b), and powdered with electric blender.

\subsection{Extraction Process}

Three hundred grams (300 g) of the powdered leaves of each plants were weighed using Satoric AG Gottingen Electronic weighing balance. The weighed powdered leaves were respectively macerated in $500 \mathrm{ml}$ of the Hexane solvent for 72 hours and filtered into conical flask using whatman No.1 filter paper (Azoro, 2000). The filtrates distinctly extracted using a rotary evaporator at $60^{\circ} \mathrm{C}$.

\subsection{Mosquito Larva Collection}

Mosquito Larvae used for this bioassay were cultured in the wild using methods as described by some authors (Rai et al., 2004; Okumu et al., 2007; Ohimain et al., 2014), with slight modification. Plastic containers and automobile tyres half-filled with stagnant water, and sand were kept in vegetation of conspicuous breeding sites. Prior to the laboratory bioassay, the larvae were placed on enamel tray and acclimatized to laboratory condition.

\subsection{Experimental Setup}

A minimum of 10 larvae, were distinctly placed in a $500 \mathrm{ml}$ solution of the methanolicextract at varying concentrations, in a 24-hour static non-renewal test. The bioassay was performed with the standard of the World Health Organization guidelines (Dibua et al., 2013). Mortality rates $(\%)$, of larvae were recorded after the period of exposure (24 hours). A concentration of $1 \mathrm{ppm}$ of Dipex pesticide was used as the positive control, while $500 \mathrm{ml}$ of distilled water was used as the negative control. The larvicidal screening protocols were twophased, involving the rapid and final Screening (Agboola et al., 2011).

\subsection{Statistical Analysis}

The data for mortality rates were expressed as mean \pm standard deviation using version 20 of SPSS statistical package. A one-way analysis of variance was used to carry out the statistical analysis, while Duncan multiple range test was used to determine the source of observed difference using SPSS Version 20.

\section{Result and Discussion}

Results of mortality rates for leaf Hexane extracts of the three plants is presented in table 2. For the Cassia alata extract, the mortality rates ranges from $26.66-100.00 \%$ significantly $(\mathrm{p}<0.05)$, with minimal and total mortalities at concentrations of 10 and $70 \mathrm{ppm}$ respectively. In addition, the positive control had total mortality at concentration of $10 \mathrm{ppm}$, compared to the negative control that showed no mortality rate (Table 1). Furthermore, results of the larvicidal efficacy of the $C$. alata hexane extract were demonstrated with $\mathrm{LC}_{50}$ value of 25.26 ppm (Figure 1).

Table 1. Biolarvicidal Mortality rates of Hexane-leaf-extracts

\begin{tabular}{lccccc}
\hline Conc. & \multicolumn{5}{c}{ Mortality Rates (\%) } \\
\hline $0 \mathrm{ppm}$ & C. alata & M. puberula & S. filicaulis & Positive & Negative \\
$10 \mathrm{ppm}$ & $0.00 \pm 0.00 \mathrm{a}$ & $0.00 \pm 0.00 \mathrm{a}$ & $0.00 \pm 0.00 \mathrm{a}$ & $0.00 \pm 0.00 \mathrm{a}$ & $0.00 \pm 0.00 \mathrm{a}$ \\
$20 \mathrm{ppm}$ & $26.66 \pm 11.54 \mathrm{~b}$ & $13.33 \pm 5.77 \mathrm{~b}$ & $10.00 \pm 0.00 \mathrm{~b}$ & $100.00 \pm 0.00 \mathrm{e}$ & $0.00 \pm 0.00 \mathrm{a}$ \\
$30 \mathrm{ppm}$ & $36.66 \pm 5.77 \mathrm{bc}$ & $20.00 \pm 0.00 \mathrm{c}$ & $16.66 \pm 5.77 \mathrm{~b}$ & $100.00 \pm 0.00 \mathrm{e}$ & $0.00 \pm 0.00 \mathrm{a}$ \\
$40 \mathrm{ppm}$ & $43.33 \pm 5.77 \mathrm{~cd}$ & $30.00 \pm 0.00 \mathrm{~d}$ & $26.66 \pm 11.54 \mathrm{c}$ & $100.00 \pm 0.00 \mathrm{e}$ & $0.00 \pm 0.00 \mathrm{a}$ \\
$50 \mathrm{pm}$ & $53.33 \pm 11.54 \mathrm{~d}$ & $40.00 \pm 0.00 \mathrm{e}$ & $30.00 \pm 0.00 \mathrm{c}$ & $100.00 \pm 0.00 \mathrm{e}$ & $0.00 \pm 0.00 \mathrm{a}$ \\
$60 \mathrm{ppm}$ & $70.00 \pm 10.00 \mathrm{e}$ & $56.66 \pm 5.77 \mathrm{f}$ & $46.66 \pm 5.77 \mathrm{~d}$ & $100.00 \pm 0.00 \mathrm{e}$ & $0.00 \pm 0.00 \mathrm{a}$ \\
$70 \mathrm{ppm}$ & $96.66 \pm 5.77 \mathrm{f}$ & $90.00 \pm 10.00 \mathrm{~g}$ & $73.33 \pm 11.54 \mathrm{e}$ & $100.00 \pm 0.00 \mathrm{e}$ & $0.00 \pm 0.00 \mathrm{a}$ \\
& $100.00 \pm 0.00 \mathrm{f}$ & $100.00 \pm 0.00 \mathrm{~g}$ & $93.33 \pm 5.77 \mathrm{f}$ & $100.00 \pm 0.00 \mathrm{e}$ & $0.00 \pm 0.00 \mathrm{a}$
\end{tabular}


Data expressed as mean \pm standard deviation, differences in alphabet indicates significance in mortality

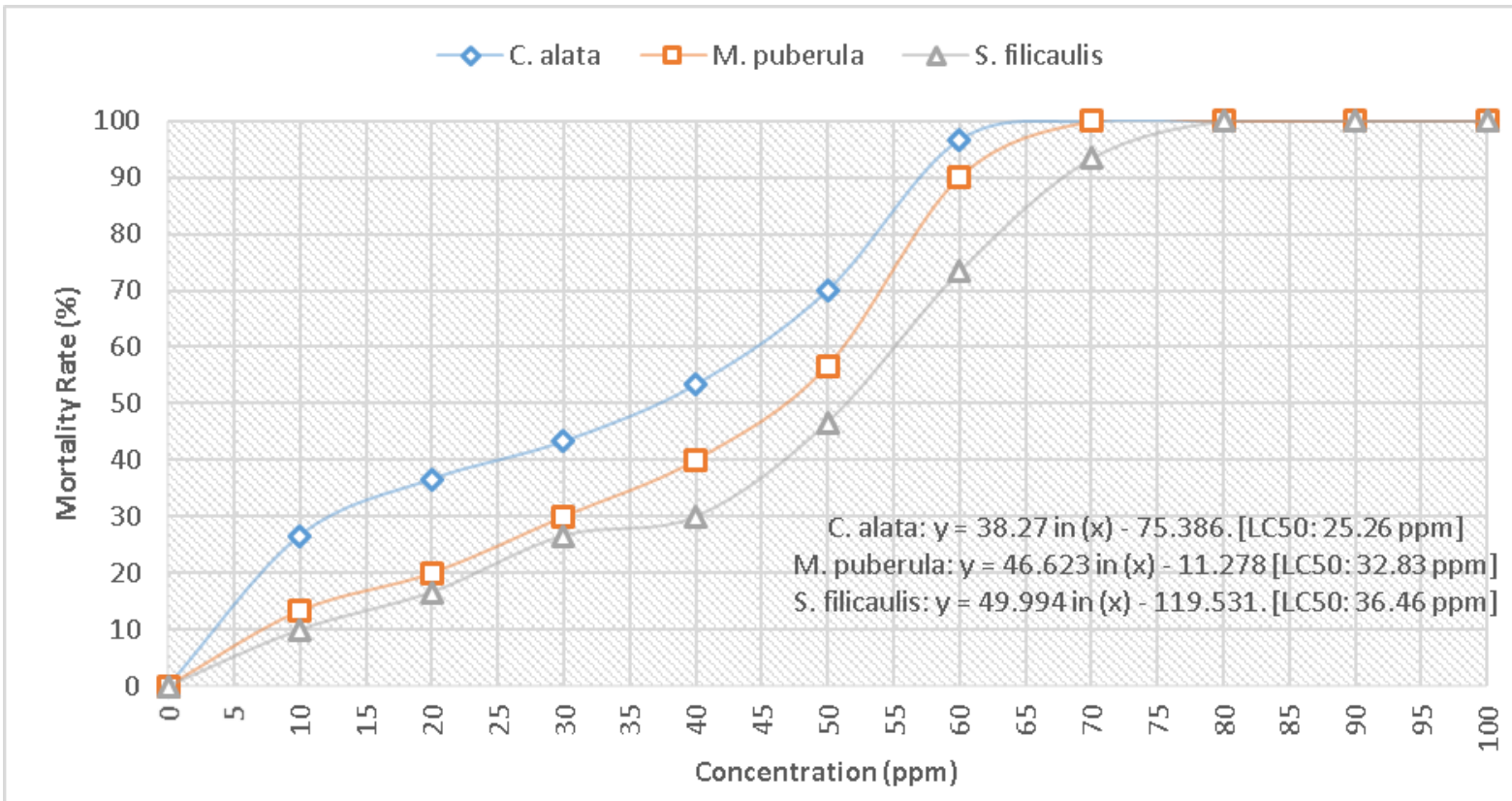

Figure 1. Biolarvicidal dose-response for Hexane-leaf-extracts of selected plant species

Results of the $M$. puberula bioassay showed that mortality rates ranges from 13.33 $100.00 \%$, with significant difference $(\mathrm{p}<0.05)$. While mortality rates increased as concentration increases (Table 1). The minimal mortality rate was reported at concentration of $10 \mathrm{ppm}$, while the total mortality was at $70 \mathrm{ppm}$. In addition, the activity of M. puberula hexane extract was demonstrated with $\mathrm{LC}_{50}$ value of $32.83 \mathrm{ppm}$ (Figure 8). The S. filicaulis biolarvicidal bioassay showed that mortality rate ranges from $10.00-100 \%$, with significant increase in mortality rate and concentration increases (Table 4.2). The minimal mortality rate was reported at concentration of $10 \mathrm{ppm}$, while the total mortality rate was displayed at 80 ppm. In addition, the no adverse effect level was at $0.00 \mathrm{ppm}$ (Table 4.2). The biolarvicidal activity of hexane extract of $S$. filicaulis was demonstrated with $\mathrm{LC}_{50}$ value of $36.46 \mathrm{ppm}$ (Figure 1).

Results reported for hexane extracts of the current study are comparable to results by other authors. Comparatively, the larvicidal activities of the hexane extracts of the bark (11.02 ppm) and root (28.08 ppm) Azadirachta indica were (Angaye et al., 2014a), induced higher activities than hexane extracts of the 3 plants in the current. The larvicidal efficacies of the hexane leaves of Niger Delta mangrove plants against Anopheles gambiae was reported with activities for Rhizophora mangle (275.63 ppm), R. racemosa $(225.00 \mathrm{ppm})$, A. germinans (250.50 ppm), and L. racemosa with value of $308.50 \mathrm{ppm}$ (Angaye et al., 2014b); these values were higher than values reported in the current study for all three plants.

The larvicidal activities of solvent extracts of Hyptis suavolens (76.25 ppm) and Ocimun sanctum (97.25 ppm) against mosquito was reported by Ohimain et al., (2015), with higher $\mathrm{LC}_{50}$ values than the current study. Sakthivadivel and Daniel (2008), reported higher LC $_{50}$ values $(62.29 \mathrm{ppm})$ than values of the current study using petroleum ether solvent extract of $J$. curcas leaves against An. stephensi. The activities of these plants were due to presence of several phytochemicals (Ohimain et al., 2015). Huge varieties of bioactive phytochemical have been previously reported in C. alata (El-mahmood and Doughari, 2008; Eliakim-Ikechukwe et al., 2013; Okooboh and Gambo, 2013; Raji et al., 2015; Ugbogu et al., 2016;), M. puberula (- 
Akpanyung et al., 2013; Gbadamosi and Oloyede, 2014; Ndam et al., 2014; Eboh et al., 2017) and S. filicaulis (Wahab et al., 2013; Ilondu et al., 2014; Fonkeng et al., 2015; Eboh et al., 2017).

\section{Conclusion}

This study investigated the biolarvicidal potential of the Hexane extracts of C. alata, $M$. puberula, and S. filicaulis. Fortunately, all plants demonstrated significant larvicidal efficacies with the $C$. alata extract demonstrating the highest efficacy, followed by $S$. filicaulis and $M$. puberula. Due to their efficacies, Hexane extracts of these plants, are hereby recommended for the formulation of larvicidal agents for the control of malaria.

\section{Acknowledgement}

The following authors wish to acknowledge Dr. Tariwari C.N Angaye for his technical assistant during the laboratory and field work.

\section{References}

Acheampong, A., Amankwaa, L. T., Afriyie, I. O. and Baah, K. A. (2018). Antioxidant and Antimicrobial Activity of the Methanol and Petroleum Ether Extracts of the Stem of Microdesmis puberula. The Pharmaceutical and Chemical Journal, 5(1), 38 - 48.

Agboola, I. O., Ajayi, G. O., Adesegun, S. A, Adesanya, S. A (2011). Comparative Molluscicidal activity of fruit pericarp, leaves, seed and stem Bark of Blighia unijugata Baker. Pharmacol. J., 3:63 - 66.

Akpanyung, E. O., Ita, S. O., Opara, K. A., Davies, K. G., Ndem, J. I., and Uwah, A. F. (2013). Phytochemical screening and effect of ethanol root extract of Microdesmis puberula on some haematological and biochemical parameters in normal male albino Wistar rats. Journal of Medicinal Plants Research, 7(31), 2338 - 2342.

Angaye T. C. N., Ohimain, E. I., Siasia, E. P., Asaigbe, P. I., Finomo, O. A. (2014b). Larvicidal activities of the leaves of Niger Delta mangrove plants against Anopheles gambiae. SkyJournal of Microbiology Research, 2(7), 032 - 036.

Angaye TCN. (2015). In-vitro comparative molluscicidal activities of aqueous and methanolic extracts of Jatropha curcas leaves against Bulinus globosus and Bulinus rholfsi; vectors of urinary schistosomiasis. M.Sc. thesis, Niger Delta University, Wilberforce Island, Bayelsa State, Nigeria.

Angaye, T. C. N., Ohimain, E. I., Zige, D.V., Didi, B., and Biobelemoye, N. (2014a). Biocidal activities of Solvent extracts of Azadirachta indica against Some Endemic Tropical Vectorborne Diseases. International Journal of Tropical Disease \& Health, 4(11), 1198 1208.

Angaye, T. C. N., Oyinke, G., Angaye, W.T., Igbeinkutu, V. D. (2017b). The Comparative Phytochemical and Bio-larvicidal Efficacy of Leaf Extracts of Gmelina arborea against Mosquito Larvae. International Journal of Innovative Healthcare Research, 5(1), 1-6.

Angaye, T. C. N., Oyinke, G., Angaye, W.T., Orubina, I. A. (2017a). Control of Malaria and Schistosomiasis Vectors Using Express Seed Sap Extracts of Gmelina arborea. Asio Journal of Medical and Health Science Research 2(1): 1 - 10.

Azoro, C. (2000). Antibacterial activity of crude extract of Azadirachita indica on Salmonella typhi. World Journal of Biotechnology, 3, 347-351.

Cheeke, P. (1998). Natural toxicants in feeds, forages, and poisonous plants. Danville, IL: Interstate. curcin, a ribosome-inactivating protein from the seeds of Jatropha curcas. Acta Bot. Sin, 45, $858-863$.

Devappa, R. K., Makkar, H. P. S., and Klaus, B. (2010). Jatropha Toxicity-A Review. Journal 
of Toxicology and Environmental Health, 13(6 Pt B): 476-507.

emails: birex.journal@gmail.com

Dibua, Uju Marie-Esther, Odo, Greg Ejikeme, Nwabor, Ozioma Forstinus, Ngwu, Goddy Ikechukwu (2013). Larvicidal activity of Picralima nitida, an environmental approach in malaria vector control. American Journal of Research Communication, 1(12), 451-469.

Eboh, A. S., Ere, D., Frank-Oputu, A. (2017). Total Phenol, Flavonoid, Tannins, Vitamin C and Spectral Analysis of Ethanolic Extract of Spilanthes filicaulis. The Saudi Journal of Life Sciences, 2(9), 331 - 334.

Eliakim-Ikechukwu, C. F., Edem, A. A., William, U. M., Okori, S. O., and Ihentuge, C.J. (2013). Phytochemical Composition of Cassia alata Leaf and its effects on Histology of Pancreas in Diabetic wistar Rats. ISOR Journal of Pharmacy and Biological Sciences, 5(5), 7 - 13.

Fonkeng, L. S., Mouokeu, R. S., Tume, C., Njateng, G. S. S., Kamcthueng, M. O., Ndonkou, N. J., and Kuiate, J. R. (2015). Anti-Staphylococcus aureus activity of methanol extracts of 12 plants used in Cameroonian folk medicine. BMC Res Notes, 8(710), $1-6$.

Gbadamosi, I. T., and Oloyede, A. A. (2014). The proximate and phytochemical Contents of Ten Nigerian Medicinal Plants used in the management of Arthritis. African Journal of Pharmacy and Pharmacology, 8(23), $638-643$.

Ghosh A., Chowdhury N., Chandra G. (2012). Review on plant extracts as potential mosquito larvicides. Indian J Med Res., 135: 581 - 598.

Ilondu E. M., Ojeifo I. M., and Emosairue, S. O. (2014). Evaluation of antifungal properties of ageratum conyzoides, Spilanthes filicaulis and tithonia diversifolia leaf extracts and search for their compounds using gas Chromatography - Mass spectrum. Journal of Agricultural and Biological Science, 9(11), 375 - 384.

Ohimain E. I, Angaye T. C. N., and Bassey, S. E. (2014). Comparative larvicidal activities of the leaves, bark, stem and root of Jatropha curcas (Euphorbiaceae) against malaria vector Anopheles gambiae. Sky Journal of Biochemistry Research, 3(3), 029 - 032.

Ohimain, E. I., Angaye, T. C. N., and Bamidele, J. F. (2015). Larvicidal Activities of Hyptis suaveolens and Ocimum sanctum against Anopheles gambiae. Journal of Applied Life Sciences International, 3(3), 131-137.

Okooboh, A. M., and Gambo, N. N. (2013). Phytochemistry and Antimicrobial Activity of the Leaf of Cassia alata LINN. Chemistry and Materials Research, 3(3), 96 - 102.

Okumu F. O, Knols B. G. J., Fillinger U (2007). Larvicidal effects of a neem (Azadirachta indica) oil formulation on the malaria vector Anopheles gambiae. Malaria Journal, 6:63.

Owoeye J. A., Akawa O. B., Akinneye J. O., Oladipupo S. O., and Akomolede, O. E. (2016). Toxicity of Three Tropical Plants to Mosquito Larvae, Pupae and Adults, Journal of Mosquito Research, 6(16), 1 - 7.

Rai, M. K., Varma, A. and Pandey, A. K. (2004). Antifungal potential of Spilanthes calva after inoculation of Piriformospora indica. Mycoses, 47, 479 - 481.

Raji, P., Sreenidhi, J., Sugithra, and Renugaddevi, K. (2015). Phytochemical Screening and bioactivity Study of Cassia alata Leaves. Biosciences Biotechnology in Asia, 12(2), 291 296.

Sakthivadivel, M., Gunasekaran, P., Sivakumar, M., Arivoli, S., Raveen, R. and Tennyson, S. (2015). Mosquito larvicidal activity of Hyptis suaveolens (L.) Poit (Lamiaceae) aerial extracts against the filarial vector Culex quinquefasciatusSay (Diptera: Culicidae). Journal of Medicinal Plants Studies, 3, 4.

Ugbogu, A. E., Okezie, E. I., Uche-Ikonne C., Duru M., and Atasie O. C. (2016). Toxicity Evaluation of the Aqueous Stem Extracts of Senna alata in Wistar Rats. American Journal of Biomedical Research, 4(4), 80 - 86.

Wahab, O. M., Ajala, O. O., Ojo, M. O., and Egunjobi A. J. (2013). Ethnomedicinal and Phytochemical profile of Spilanthes filicaulis (Schum \& Thonn) CD Adams (Astaraceae) in Ibadan metropolis. Heal. Herbs Pract Technol., 2, 13 - 18. 